大阪大学医学部, 第 3 解剖学教室 (主任: 黑津敏行教授).

3rd Dept. of Anat., Osaka Univ. Med. School (Director : Prof. T. KUROTSU).

\title{
交連下器官の分泌路についで*
}

On the Secretory Pathway of the Subcommissural Organ.

\author{
阔田正雄 Masao OKADA.
}

(昭和 30 年 9 月 10 日原稿受付.)

交連下器官が形態学的飞特異な脳室上衣細胞からなり，こ」に分泌現象 のあることは既に古くから推測されていたが，最近視床下部一下垂体神経 分泌系の追求飞際し，この交連下器官の細胞にも Gomori 氏（1941，1950） のchrom-alum hematoxylin 或は aldehyde-fuchsin 飞選択的飞染る分泌顆 粒の存在を確認し, 更にこの器官に由来すると考兄られる Reissner 氏線 維も同じ染性を示すととから，この器官で分泌された顆粒は Reissner 氏 線維を通って下行すると想定される様となった（Bargmann と Schiebler 1952, Wislocki と Leduc 1952, 1954, Stutinsky 1953, Wingstrand 1954). けれども私はBufo vulgaris を用い，この器官に別の分泌路の存在を推定 させる所見を得たので報告する.

\section{I. 実験材料と方法.}

5 月初旬大阪で得た成熟Bufo vulgaris を用い，これをBouin 氏液で 生体固定を施し，直ちに脳䯣を摘出し，更にZenker 氏液で 6 時間, Bouin 氏液で 2 日間阁定した。. 次に所定の操作で $6 \mu$ のパラフィン連続切片とな し，これをGomori（1941）氏法の前処置を施した後 Halmi（1952，1953） 氏の aldehyde-fuchsin 法で染色標本を作製した. 尚別のBufo vulgarisを アルコールで生体固定し, Schwank とPrados（1942）法飞よって $20 \mu の$ 鍍銀標本を作製し，補助的ととの所見を追求した。

\section{II. 所見.}

後交連の下部に接して存在する交連下器官は他の脳室上衣細胞と異り, 一層の脊の高い細胞からなっている。この細胞体には他の部と異り aldehyde-fuchsin で濃青黒色飞染る微小顆粒が認められるが，この顆䊀は特に その脳室側に多数集って濃染しているし，この細胞から発すると考兄られ

*本論文の要旨は昭和 30 年10月日本脳神経外科学会飞於ける黑津教授の特別講演の 一部として発表された。 
ている Reissner 氏線維も亦, 等質性の榇状となって濃染し下行している (罒1)。この事は街来から考えられている交連下器官より Ressner 氏線維

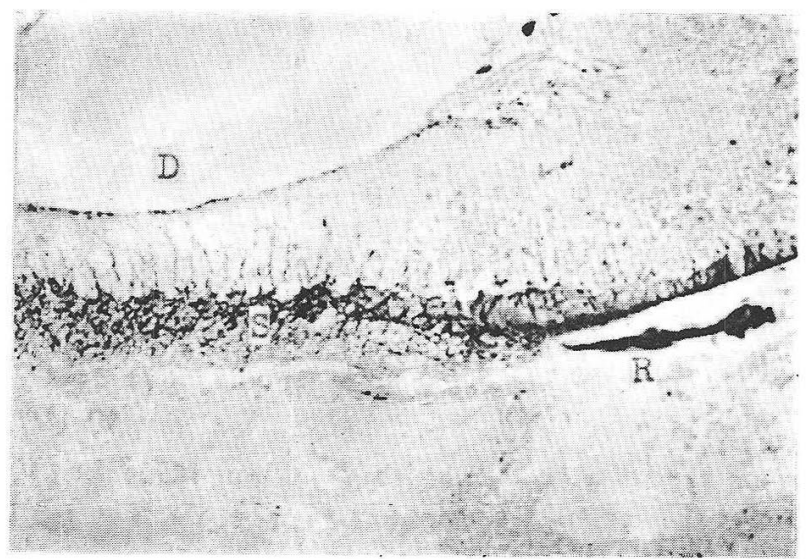

Fig. 1. Photograph showing the subcommissural organ (S) and REISSNER's fiber ( $R$ ) of Bufo vulgaris. Many fibers containing the granules run from the subcommissural organ to the dorsal surface of the mid-brain (D) through the posterior commissure. $6 \mu$ para-sagital section, a modification of HALMI's staining. $\times 135$.

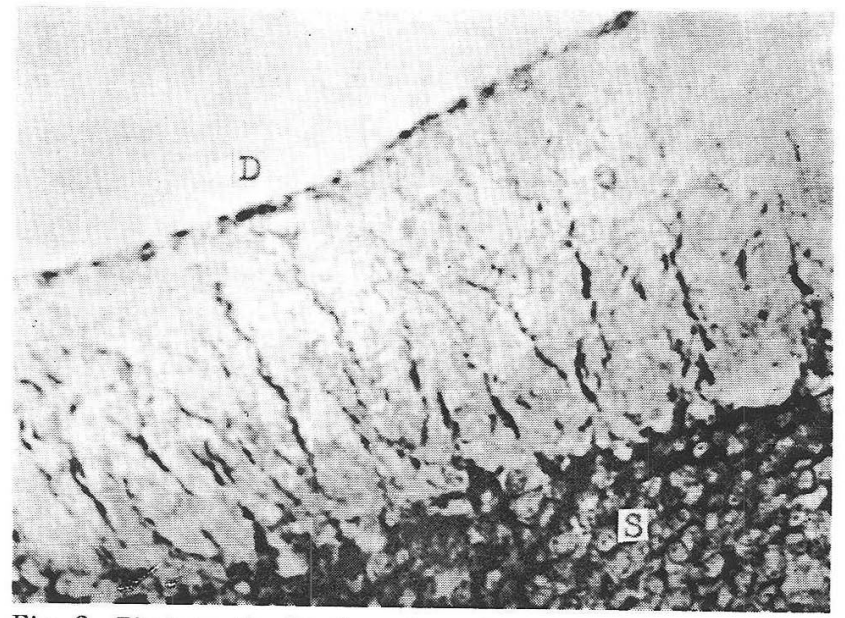

Fig. 2. Photograph showing the subcommissural organ (S) of Bufo vulgaris and the fibers which run from the subcommissural organ to the dorsal surface of the mid-brain (D) through the posterior commissure and contain many granules. The granules accumulate at the end of the fibers in the dorsal surface. $6 \mu$ para-sagital section, a modification of HALMI's staining. $\times 360$. 


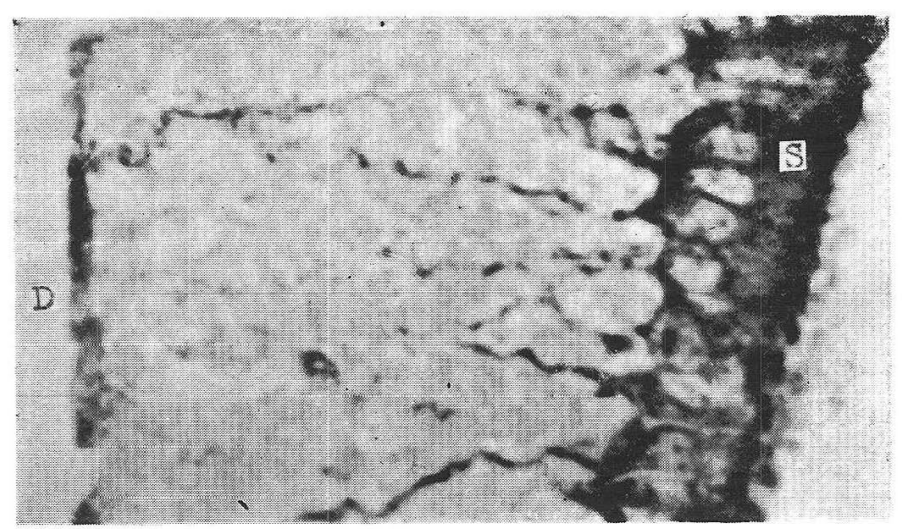

Fig. 3. Photograph showing the subcommissural organ (S) and the fibers containing many granules in Bufo vulgaris. A fiber runs from the subcommissural organ to the dorsal surface of the mid-brain (D), and the granules within the fiber accumulate on the surface of the mid-brain. $6 \mu$ sagittal section, a modification of HALMI's staining. $\times 450$.

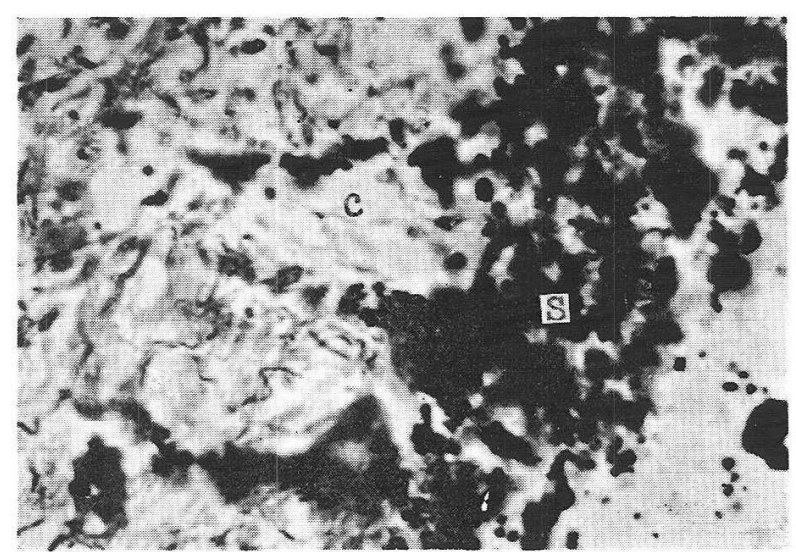

Fig. 4. Photograph showing granules in the subcommissural organ (S) and in the posterior commissure (C) of Bufo vulgaris. Some granules enter into the posterior commissure from the subcommissural organ. $20 \mu$ sagittal section. silver impregnation. $\times 1350$.

への分泌路を推定し得るのであって，Wislocki と Leduc（1952）其の他の みた種々の哺乳動物に於ける所見に䀩一致している。

ところがに涪の所見とは別に交連下器官細胞の後交連側にも同じ染悱の 顆粘が著しく集って浱染し，この細狍から背方に走る線維に㯖って，この

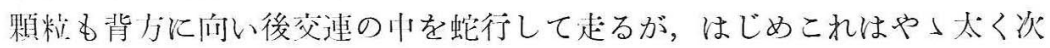


第に細くなる傾向を示し，遂に後交連を貫いて，その部の脳質背側壁飞終 っている．又この中脳背側壁飞あるとの末端には比較的多数の顆粒が集っ て，あたかもこ〉に排出されたと思われる像を示している（罒 1，2，3）. ところがこの線維は極めて多数でしかも背側飞向いほ心゙平行して走るから， 從って中脳背側壁の終未部に認められる顆粒の塊りも，この壁飞深って全 面に招よそ連続的に認められる（罒 1，2）。

尚鍍銀標本によっても交連下器官には他の脳室上衣細胞と異り多数の大 型顆粒が充満している. ところがこの顆粒群からその一部が矢張り背方に 向って後交連内に入り込んでいる像を屢々認める（図4）. この場合は後 交連の背側部までこれを追跡出来なかったが，矢張り交連下器官細胞内の 分泌顆粒が背方飞向うことを推知し得ると思う。勿論前記の aldehydefuchsin 陽性顆粒とこの鍍銀標本とみる顆粒とる゙直ちに同一物であるとは 文觉ないが，どちらも分泌顆粘の形態を示すので，分泌径路を推定する上 に於て後者は前者の参考飞なる.

\section{III. 考 察.}

交連下器官の aldehyde-fuchsin 陽性顆粒が脳室側飞分泌され，これが恐 らくReissner 氏線維を介して流れ下るという仮説は私も上記形態学的所 見から或程度その根拠があると思うし，これとついては既に Wislocki と Leduc (1952, 1954), Stutinsky (1953), Wingstrand（1954）等が組織学 的或は組織化学的飞推論している。ところが私はこれと別と交連下器官の 分泌顆粒が後交連を貫いて背方に走り, 中脳の背側壁飞至る像を認めたの であって，これは恐らくその部の脳膜挖内飞排出されるものと考劣る.

Bargmann そ Schiebler (1952), Wislocki と Leduc (1952，1954）等は哺 乳類で後交連と交連下器官の間に Hypendym 層の存在を示し, こ〉とあ るグリア細胞内に chrom-alum hematoxylin 或は aldehyde-fuchsin 陽性の 物質を認めているが，それ自身分泌顆粒とは未だ認め難い様であるし，更 に又これが分泌形態を示す像もない．これに反して私のみた背方に向って 連続的飞走る顆粒は, 明か飞交連下器官細胞から発して招り, しかもグリ ア細胞と特飞密接な関係が無さそうであるから, 前記諸家の Hypendym 層に認めたグリア細胞内の物質とは全く異ると思う。

交連下器官の顆粒と視床下部-下垂体神経分泌系の顆粒とは aldehydefuchsin 飞共飞選択的飞染るが，Mazzi（1954）はアルコール固定をすると 後者は染性を失うのに, 交連下器官飞存在する顆粒は染性を失わないこと から, 又 Wingstrand（1954）は発生学的にみて交連下器官には独立して 
早期に顆精が出現するとと等から, 交連下器官の分泌顆精はこ〉の細胞で 形成される特殊なるのと考光ている. 分泌顆粒が交連下器官細胞で造られ ることは上述の私の所見からも明かであるが，更とこれが Wislocki 等の いうよう飞脳室側飞分泌されて, Reissner 氏線維に沿って排出されると 思われる像（罒1）の他に, 直接髄液中に排出されると思われる像（眓 3 ） を認めたが，この点更に詳細に検索する積りである.

\section{IV. 結語。}

Bufo vulgaris の交連下器官を aldehyde-fuchsin 染色と鍍銀で追求し, 交連下器官の分泌顆粒が後交連を貫き背方に向って走り, 中脳背側壁に至 り, こ〉の脳膜腔に排出されるものと思われる形態学的所胃を認めた。

終りに臨み, 御懇篤な御指導と御校閱を賜った黑津教授, 伴助教授に感謝の意を表 します。

\section{Author's Abstract.}

The author investigated the secretory pathways of the subcommissural organ of Bufo vulgaris by a modification of HALMI's staining and the silver impregnation, and obtained following results.

Secretory granules in the cells of the subcommissural organ run in a winding line from the dorsal pole of the cells of the organ towards the dorsal surface of the mid-brain through the posterior commissure, and the granules accumulate on the end of the granular fiber at the dorsal surface of the mid-brain. From these morphological feature, it is supposed that the secretory granules of the subcommissural organ are secreted into the dorsal meningeal space.

It is also supposed that some of the secretory granules in the cells of the subcommissural organ are secreted ventrally into the REISSNER's fiber or directly into the cerebrospinal fluid in the ventricle, as demonstrated by some investigators.

\section{文献.}

Bargmann, W. u. Th. H. Schiebler: Histologische und zytologische Untersuchungen am Subcommissuralorgan von Säugern. Z. Zellforsch. 37 (1952). S. 583. - Gomori, G. : Observations with differential stains on human islets of Langerhans. Amer. J. Path. 17 (1941). P. 395. - Aldehyde-fuchsin; a new stain for elastic tissue. Amer. J. clin. Path. 20 (1950). P. 665. - Halmi, N. S.: Differentiation of two types of basophilis in the adenohypophysis of the rat and mouse. Stain Tech. 27 (1952). P. 61. - Halmi, N. S. a. J. Davies : Some 
further staining properties of aldehyde-fuchsin (abstract). Anat. Rec. 115 (1953). P. 316. - Mazzi, V.: Arch. Zool. Ital. 37 (1952). P. 445. Cited from Enami, M.: Endoc. japon. 1 (1954). P. 133. - Stutinsky, F. : La neurosécrétion chez l'anguille normale et hypophysectomisée. Z. Zellforsch. 39 (1953). P. 276.

Swank, R. L. a. M. Prados: Avian thiamine deficiency, II. Pathologic changes in the brain and cranial nerves (especially the vestibular) and their relation to the clinical behavior. Arch. Neur. a. Psychiat. 47 (1942). P. 91 . - Wingstrand, K. G. : The ontogeny of the neurosecretory system in chick embryos. Pubbl. Staz. zool. Napoli. 24 (Suppl.) (1954). P. 25. - Wislocki, G. B. a. E. H. Ledue : The cytology and histochemistry of the subcommissural organ and Reissner's fiber in rodents. J. comp. Neur. 97 (1952). P. 515. - The cytology of the subcommissural organ, Reissner's fiber, periventricular glial cells and posterior collicular process of the rat's brain. J. comp. Neur. 101 (1954). P. 283. 